\author{
dr Beata MADRAS-KOBUS \\ Wydział Ekonomii i Zarządzania, Uniwersytet w Białymstoku \\ e-mail: b.kobus@uwb.edu.pl \\ dr hab. Józef ROGOWSKI, prof. UwB \\ Wydział Ekonomii i Zarządzania, Uniwersytet w Białymstoku \\ e-mail: rogowski@uwb.edu.pl
}

DOI: $10.15290 /$ ose.2016.04.82.08

\title{
STOPY BEZROBOCIA WŚRÓD OSÓB Z RÓŻNYM WYKSZTALCENIEM W WOJEWÓDZTWACH POLSKI - ANALIZA WYNIKÓW BADANIA
}

W artykule dokonano krótkiego przeglądu różnych metodologii obliczania stóp bezrobocia stosowanych przez Główny Urząd Statystyczny w Polsce oraz zaproponowano pewną ich modyfikację. Obliczono stopy bezrobocia według zaproponowanej metodologii w województwach Polski, w podziale na rodzaj wykształcenia, tj.: wyższe, policealne i średnie zawodowe, średnie ogólnokształcące, zasadnicze (zawodowe) oraz gimnazjalne, podstawowe i niepełne podstawowe. Na podstawie tak otrzymanych stóp bezrobocia województwa Polski podzielono na grupy o podobnym kształtowaniu się poziomu tego wskaźnika. Dokonano analizy otrzymanych wyników.

Słowa kluczowe: bezrobocie, stopa bezrobocia rejestrowanego, stopa bezrobocia według BAEL, aktywni zawodowo, skupienia

\section{UNEMPLOYMENT RATES BY EDUCATIONAL ATTAINMENT IN POLAND: AN ANALYSIS OF RESEARCH RESULTS}

\section{Summary}

The paper provides a brief review of various methodologies for calculating unemployment rates applied by Główny Urząd Statystyczny (Central Statistical Office) in Poland and proposes certain modifications to these methodologies. Unemployment rates for the provinces of Poland have been calculated based on the suggested methodology for the following levels of education: tertiary, postsecondary and secondary vocational, secondary general, basic vocational and lower secondary, primary and incomplete primary education. An analysis of the results is conducted. On this basis, the provinces of Poland are grouped into clusters according to the calculated unemployment rates.

Key words: unemployment, registered unemployment rate, unemployment rate according to LFS (Labour Force Survey), economically active persons, clusters

JEL: R23 


\section{Wstęp}

Bezrobocie jest jednym z ważniejszych i bardziej dokuczliwych skutków transformacji ustrojowej, jaką przeszła gospodarka polska w latach dziewięćdziesiatych XX wieku [szerzej: Szydlik-Leszczyńska, 2012, s. 26 i nast.]. Obserwacje sytuacji na polskim rynku pracy w ostatnich kilkunastu latach pokazuja, że również na początku XXI wieku jest to bardzo istotny problem społeczno-gospodarczy. Pewna poprawę sytuacji przyniosło wstapienie Polski w struktury Unii Europejskiej. Z jednej strony pojawiły się środki finansowe w ramach programów operacyjnych: 14 mld euro w perspektywie 2004-2006 oraz 67,5 mld euro w ramach perspektywy finansowej 2007-2013 [Fundusze Europejskie w Polsce ..., 2014, s. 1]. Wpływały one na przyspieszenie wzrostu gospodarczego w Polsce, zwiększone nakłady na inwestycje i korzystnie oddziaływały na sytuację na rynku pracy. Z drugiej strony otworzyły się rynki pracy w krajach Unii Europejskiej. Polacy mogli wyjeżdżać $z$ kraju bez wiz i podejmować legalną pracę za granica. Powyższe czynniki spowodowały, że na polskim rynku pracy pojawiły się pozytywne zmiany. Stopa bezrobocia, która do 2003 roku ciagle rosła, od 2004 roku zaczęła spadać [Nagaj, 2009, s. 15-17]. Korzystne zmiany na rynku pracy odczuwają nie tylko bezrobotni, ale także ich rodziny, gdyż zjawisko to i jego negatywne skutki należy rozpatrywać w szerszej perspektywie [Kozek, 2013, s. 38]. Wyniki wielokrotnie przeprowadzonych badań wskazuja, że wraz ze wzrostem wykształcenia zmniejsza się poziom bezrobocia, ponadto umiejętności zawodowe poprawiają sytuację bezrobotnych na rynku pracy [Kołodziejczak, Wysocki, 2013, s. 47].

Celem niniejszego artykułu jest analiza wpływu wykształcenia na poziom bezrobocia w województwach Polski. W badaniach zastosowano jedynie podział osób bezrobotnych ze względu na kryterium wykształcenia. Nie analizowano bezrobocia w podziale na płeć i czas pozostawania bezrobotnym, jak również nie uwzględniono przepływów zasobów siły roboczej na rynku pracy.

\section{Metodologie obliczania stóp bezrobocia}

Do ilościowej analizy zjawiska bezrobocia najczęściej wykorzystuje się stopę bezrobocia. Jednak można przyjąć różne metodologie obliczania tego współczynnika. Różnia się one przyjętymi definicjami i sposobami gromadzenia danych.

Jedno z podejść do tego zjawiska jest charakteryzowane przez stopę bezrobocia rejestrowanego. Posługuje się ona statystykami rynku pracy prowadzonymi przez urzędy pracy. Stopę bezrobocia rejestrowanego oblicza się [Bezrobocie rejestrowane..., 2016, s. 8] jako stosunek liczby bezrobotnych zarejestrowanych do liczby cywilnej ludności aktywnej zawodowo, tj. bez osób odbywających czynną służbę wojskową oraz pracowników jednostek budżetowych prowadzących działalność w zakresie obrony narodowej i bezpieczeństwa publicznego. Przez pojęcie cywilnej ludności aktywnej zawodowo szacowanej na koniec każdego okresu należy rozumieć osoby pracujące w jednostkach sektora publicznego i prywatnego, a także osoby bezrobotne. Stopę bezrobocia podaje się z uwzględnieniem pracujących w gospodarstwach indywidualnych w rolnictwie (będących składową cywilnej ludności aktywnej zawodowo) wyszaco- 
wanych na podstawie wyników spisów. Jednak stopa bezrobocia rejestrowanego jest miara obarczoną pewnymi błędami. Liczba zarejestrowanych bezrobotnych zależy od motywacji osób bezrobotnych do rejestracji w urzędzie pracy. Jeśli szansa na znalezienie pracy za pośrednictwem urzędu pracy jest niewielka, taka motywacja nie występuje. Skutkuje to zaniżeniem faktycznej stopy bezrobocia. Z drugiej strony, jeśli bezrobotny zarejestrowany może liczyć na pewne profity, np.: udział w szkoleniach, prawo do zasiłku, powoduje to zwiększenie motywacji do rejestracji i zawyżenie faktycznej skali bezrobocia. Ponadto, zwiększenie np. wysokości zasiłku nasila motywację do rejestracji, zaś utrata prawa do jego otrzymania może wpłynąć na zaniżenie motywacji do rejestracji.

Inną metodologię przyjmuje się wyznaczając stopę bezrobocia według Badania Aktywności Ekonomicznej Ludności (BAEL). Wykorzystuje ono metodę reprezentacyjną, która umożliwia uogólnianie wyników badania na populację generalną [Ak.tywność ekonomicz̧na ludności..., 2015, s. 12]. Badania przeprowadza się na reprezentatywnej próbie osób w wieku 15 i więcej lat. W trakcie Badania Aktywności Ekonomicznej Ludności zostaje ustalona liczba osób aktywnych zawodowo, równa sumie pracujących i bezrobotnych. Podstawą metodologii BAEL są definicje przyjęte na XIII Międzynarodowej Konferencji Statystyków Pracy w październiku 1982 roku i zalecane do stosowania przez Międzynarodową Organizację Pracy. Przedmiotem badania jest sytuacja w zakresie aktywności ekonomicznej ludności, tzn. fakt wykonywania pracy, pozostawania bezrobotnym lub biernym zawodowo w badanym tygodniu. Wyszczególniona jest równocześnie grupa biernych zawodowo, czyli tych, których nie sklasyfikowano ani jako pracujących, ani jako bezrobotnych. Do bezrobotnych zalicza się także osoby, które znalazły pracę, czekają na jej rozpoczęcie (do trzech miesięcy) i jednocześnie deklarowały chęć jej podjęcia.

Według BAEL, do pracujacych zalicza się wszystkie osoby w wieku 15 lat i więcej, które w okresie badanego tygodnia:

- $\quad$ wykonywały, przez co najmniej godzinę, pracę przynosząca zarobek lub dochód;

- $\quad$ prowadziły własna działalność gospodarczą poza rolnictwem;

- miały pracę, ale jej nie wykonywały (z różnych przyczyn).

Do pracujących - zgodnie z międzynarodowymi standardami - byli zaliczani zarazem uczniowie, którzy otrzymywali wynagrodzenie w ramach zawartej umowy o naukę zawodu lub przyuczenie do określonej pracy.

Aby osoba została uznana za bezrobotną według BAEL, musi spełniać następujące warunki łącznie:

- być w wieku 15-74 lata;

- nie pracować w okresie badanego tygodnia;

- $\quad$ aktywnie poszukiwać pracy (konkretne działania w okresie czterech tygodni przed badaniem, wliczając w to tydzień badania);

- $\quad$ być gotową do podjęcia pracy w ciagu dwóch tygodni po przeprowadzeniu badania.

Zgodnie z BAEL, stopa bezrobocia jest obliczana jako procentowy udział bezrobotnych w liczbie aktywnych zawodowo, uwzględniający definicje Międzynarodowej 
Organizacji Pracy [Aktymność ekonomicžna ludności..., 2015, s. 20]. Ta metoda liczenia stopy bezrobocia również nie jest wolna od wad. Wyniki uzyskane na podstawie badań ankietowych są obciążone błędem próby losowej. Jeśli próba losowa jest odpowiednio duża (tak dzieje się w przypadku badań krajowych), to błąd ten jest niewielki. Jednak w szacunkach regionalnych błędy są już znaczące. Natomiast niewątpliwą zaletą takiej metodologii szacowania bezrobotnych jest standaryzacja przyjętych definicji i zasad obliczeń, co pozwala na porównywanie wyników otrzymanych dla rynków pracy różnych krajów.

Stopy bezrobocia publikowane przez GUS, obliczane według obu powyższych metodologii, podawane są najczęściej według płci, wieku, miejsca zamieszkania. Nie są publikowane kwartalne stopy bezrobocia zgodnie z kategorią wykształcenia w województwach.

W niniejszych badaniach autorzy zastosowali inną metodologię obliczania tego wskaźnika, będąca modyfikacja powyższych metodologii. Stopa bezrobocia została obliczona jako stosunek liczby bezrobotnych zarejestrowanych $z$ danym wykształceniem przez liczbę osób zdolnych do pracy w wieku 15-64 lata z tym samym wykształceniem [szerzej: Madras-Kobus, Rogowski, 2013, s. 104]. Liczbę osób zdolnych do pracy w wieku 15-64 lata $\mathrm{z}$ danym wykształceniem obliczono jako iloczyn liczby aktywnych zawodowo w wieku 15-64 lata (według BAEL) i udziału ludności w wieku 15-64 lata według poziomu wykształcenia w ogólnej liczbie ludności w tym wieku (według BAEL).

W artykule dokonano podziału ludności ze względu na wykształcenie:

- wyższe;

- policealne oraz średnie zawodowe;

- średnie ogólnokształcące;

- zasadnicze (zawodowe);

- gimnazjalne, podstawowe i niepełne podstawowe.

\section{Wyniki badań empirycznych}

W badaniach posłużono się danymi z Banku Danych Lokalnych pochodzące z publikacji Głównego Urzędu Statystycznego, dostępne na stronie www.stat.gov.pl. Analizę przeprowadzono dla kolejnych kwartałów z lat 2005-2015. Do obliczeń wykorzystano program Excel oraz SPSS (analiza taksonomiczna).

\subsection{Analiza stóp bezrobocia wśród osób z wykształceniem wyższym}

W Polsce wśród osób z wykształceniem wyższym najniższą stopę bezrobocia w całym analizowanym okresie zaobserwowano w województwie mazowieckim. Niskie stopy bezrobocia pojawiły się także w województwach: wielkopolskim, śląskim, pomorskim oraz łódzkim (wykres 1.). Najniższa średnia stopa bezrobocia $(3,86 \%)$ była w województwie mazowieckim, jednak stwierdzono tam dość wysoki poziom współczynnika zmienności (19,17\%). Wynikało to najprawdopodobniej ze zmian koniunktury gospodarczej $\mathrm{i}$ trendu zmian bezrobocia w badanym okresie, a nie ze zmian sezonowych, gdyż te prawie nie wystapiły. Od poziomu 4,66\% w I kwartale 2005 
roku stopa bezrobocia w województwie mazowieckim malała aż do poziomu 2,4\% w I i II kwartale 2008 roku, a następnie wzrosła do 5,19\% w I kwartale 2013 roku i ponownie zmniejszyła się do 3,31\% na koniec 2015 roku.

WYKRES 1.

Najniższe stopy bezrobocia osób z wykształceniem wyższym w latach 2005-2015

mazowieckie

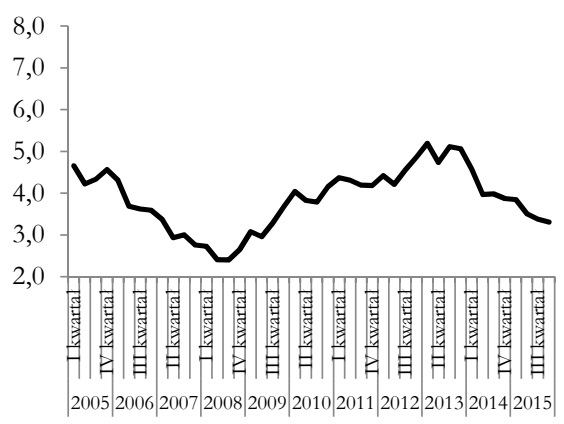

wielkopolskie

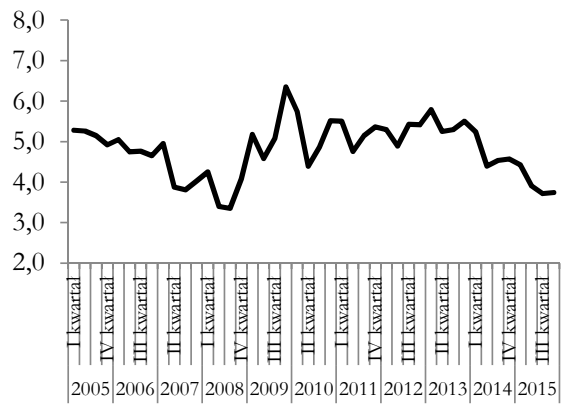

pomorskie

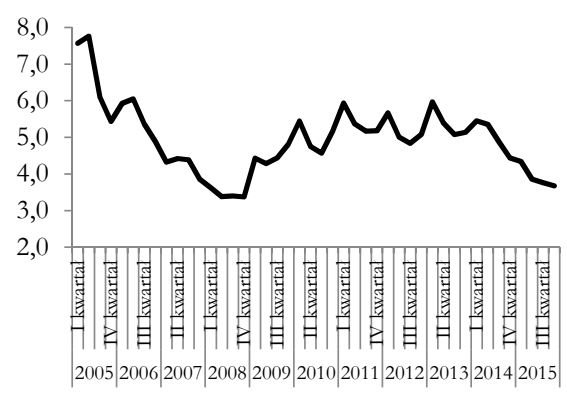

łódzkie

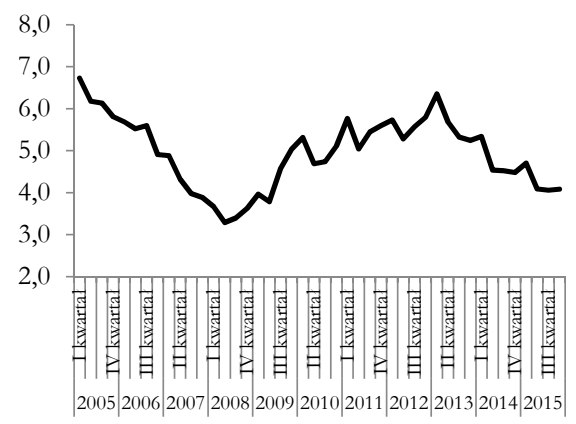

śląskie

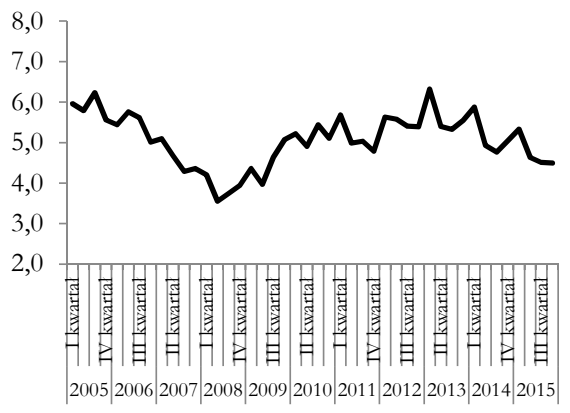

Źródło: opracowanie własne na podstawie: [www.stat.gov.pl, data wejścia: 11.03.2016]. 
Można zauważyć, że najwyższa stopa bezrobocia w województwie mazowieckim była 2,1 razy większa od najniższej w badanym okresie.

WYKRES 2.

Najwyższe stopy bezrobocia osób z wykształceniem wyższym w latach 2005-2015

podkarpackie

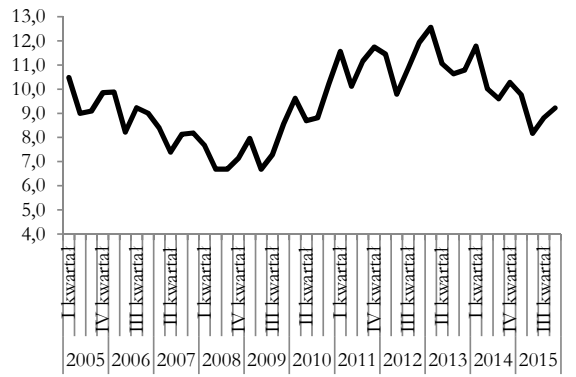

warmińsko-mazurskie

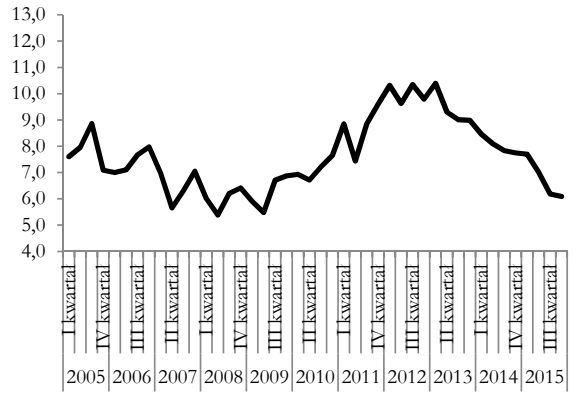

lubelskie

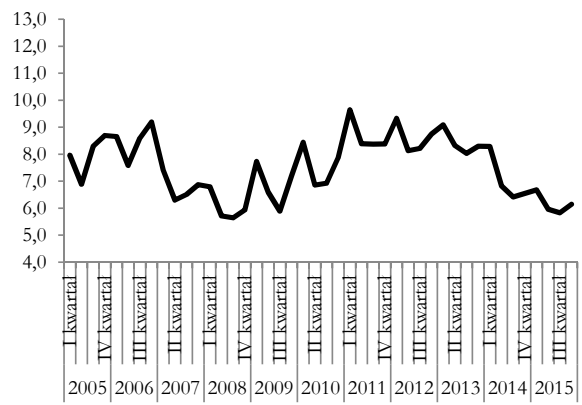

świętokrzyskie

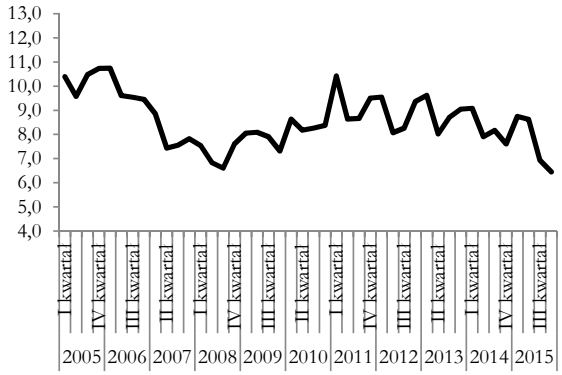

zachodniopomorskie

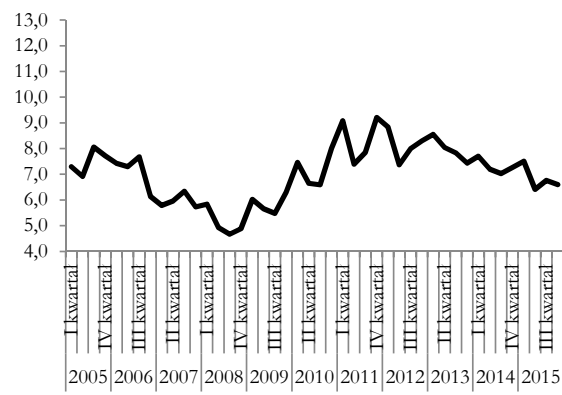

Źródło: opracowanie własne na podstawie: [www.stat.gov.pl, data wejścia: 11.03.2016]. 
W województwie tym nie występowały zbyt duże zmiany analizowanego wskaźnika między kwartałami. Natomiast wśród innych województw, zwłaszcza tych o wysokiej stopie bezrobocia, można było zauważyć silne zmiany. Niska średnia stóp bezrobocia, poniżej 5\%, miała miejsce w takich województwach, jak: łódzkie, pomorskie oraz wielkopolskie. Najwyższą średnią stóp bezrobocia (9,41\%) zaobserwowano w województwie podkarpackim. Bezrobocie w tym województwie charakteryzowało się dość silnymi zmianami międzykwartałowymi. Świadczy to o podejmowaniu prac sezonowych, czyli wymagających niższych kwalifikacji, przez osoby z wyższym wykształceniem.

Najwyższa stopa bezrobocia pojawiła się w województwie podkarpackim i świętokrzyskim, a od III kwartału 2011 roku do województw o najwyższej stopie bezrobocia dołączyło także województwo warmińsko-mazurskie. Wysoka stopa bezrobocia wśród osób z wykształceniem wyższym występowała również w województwach: lubelskim oraz zachodniopomorskim (wykres 2.). Najwyższa w badanym okresie stopa bezrobocia (12,56\% w I kwartale 2013 roku) w województwie podkarpackim była 1,9 razy większa od najniższej (6,68\% w III kwartale 2008 roku). Wysokie średnie stóp bezrobocia, powyżej 7\%, odnotowano w województwach: świętokrzyskim, lubelskim, warmińsko-mazurskim oraz zachodniopomorskim. Jednocześnie w tych województwach zaszły zmiany sezonowe. W województwach tych są wysoko rozwinięte: turystyka oraz rolnictwo i rybołówstwo, czyli te gałęzie gospodarki, w których zapotrzebowanie na pracę charakteryzuje się silną sezonowością. Innowacyjne gałęzie przemysłu są w nich słabiej rozwinięte, stąd mniejsze zapotrzebowanie na pracowników z wyższym wyksztalceniem.

We wszystkich województwach stopy bezrobocia wśród osób z wykształceniem wyższym malały w okresach od 2005 do 2008 roku oraz od 2013 do 2015 roku, natomiast w latach 2009-2012 odnotowano ich wzrost. Można zauważyć, że wzrost był znaczący i analizowane stopy bezrobocia na początku roku 2013 były wyższe niż na początku badanego okresu, czyli w 2005 roku. Jednak spadek stóp bezrobocia w drugim okresie był mniejszy niż w pierwszym i na koniec roku 2015 wskaźnik ten w województwach, mimo że wyższy niż w roku 2008, to był niższy niż na początku badanego okresu, co jest dowodem korzystnych zmiana na rynku pracy wśród osób z wykształceniem wyższym.

\subsection{Analiza stóp bezrobocia wśród osób z wykształceniem policealnym i średnim zawodowym}

Wśród osób z wykształceniem policealnym i średnim zawodowym w kolejnych kwartałach lat 2005-2008 odnotowano znaczący spadek stóp bezrobocia we wszystkich województwach, a od początku roku 2009 nieznaczny wzrost do końca roku 2012, po którym nastąpił niewielki spadek. Jednakże w badanym okresie można stwierdzić, że stopa bezrobocia wśród osób z tym wykształceniem we wszystkich województwach istotnie spadła. Świadczy to korzystnie o zapotrzebowaniu na pracowników z wykształceniem policealnym oraz średnim zawodowym na rynku pracy w Polsce. Umiejętności posiadane przez absolwentów szkół policealnych i zawodowych są docenianie przez 
pracodawców i potrzebne w gospodarce. Najniższą średnią stóp bezrobocia zaobserwowano w województwie śląskim $(8,18 \%)$. Mimo to była ona znacznie wyższa od najniższych średnich stóp bezrobocia wśród osób z wykształceniem wyższym. Przekroczyła ona najniższa średnią stóp bezrobocia osób z wykształceniem wyższym o 4,32 p.p. Niskie stopy bezrobocia (średnia: poniżej 10\%) w badanym okresie wśród osób z wykształceniem policealnym i średnim zawodowym występowały również w województwach: mazowieckim, łódzkim oraz wielkopolskim (wykres 3.). Jednak w tych województwach występował także wysoki współczynnik zmienności (powyżej 20\%). Może to wynikać ze znacznych zmian stóp bezrobocia w całym analizowanym okresie. Przykładowo w województwie śląskim maksymalna wartość wskaźnika wynosiła 13,34\% (w I kwartale 2005 roku), a najniższa 5,28\% (w III kwartale 2008 roku). Najwyższa w badanym okresie stopa bezrobocia (13,34\% w I kwartale 2005 roku) w województwie śląskim była 2,5 razy większa od najniższej (5,28\% w III kwartale 2008 roku).

WYKRES 3.

\section{Najniższe stopy bezrobocia osób z wykształceniem policealnym i średnim zawodowym w latach 2005-2015}

śląskie

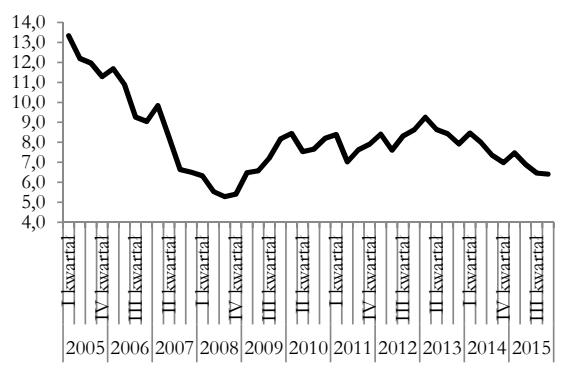

mazowieckie

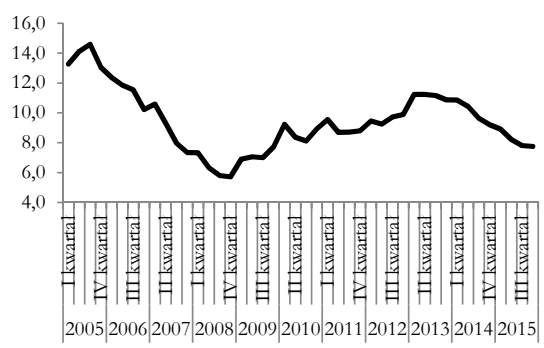

łódzkie

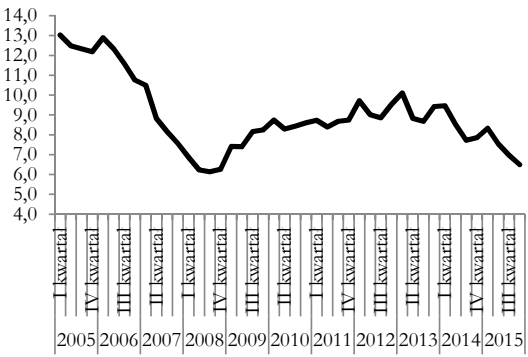

wielkopolskie

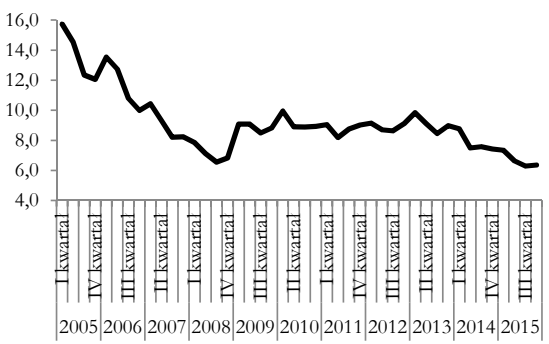

Źródło: opracowanie własne na podstawie: [www.stat.gov.pl, data wejścia: 11.03.2016].

Najwyższe stopy bezrobocia w latach 2005-2008 były w województwach: zachodniopomorskim (średnia: 14,21\%) oraz warmińsko-mazurskim (średnia: 15,87\%), a od roku 2009 w podkarpackim (średnia: 15,44\%) i warmińsko-mazurskim (wykres 4.). 
WYKRES 4.

Najwyższe stopy bezrobocia osób z wykształceniem policealnym i średnim zawodowym w latach 2005-2015

podkarpackie

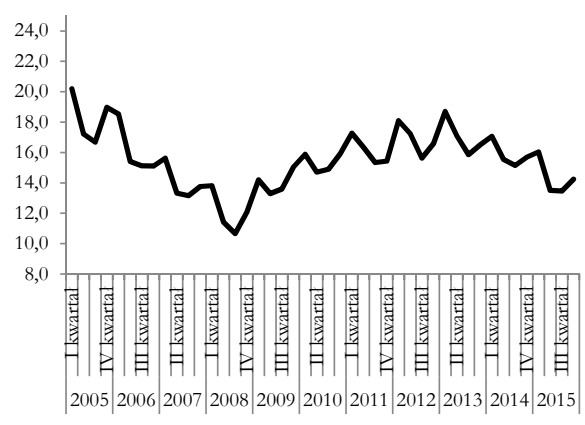

warmińsko-mazurskie

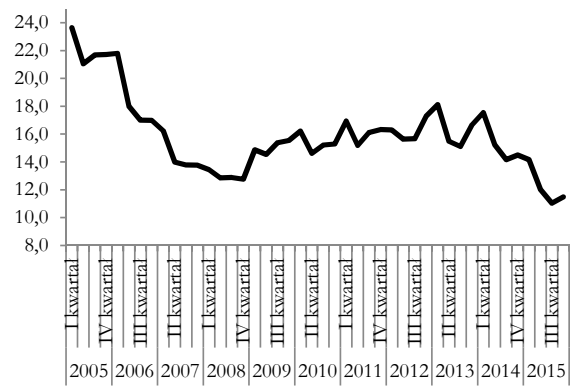

świętokrzyskie

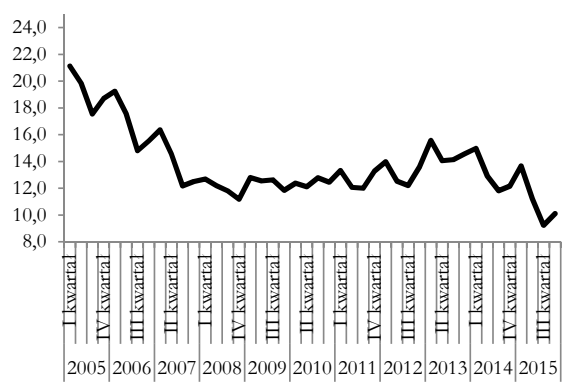

kujawsko-pomorskie

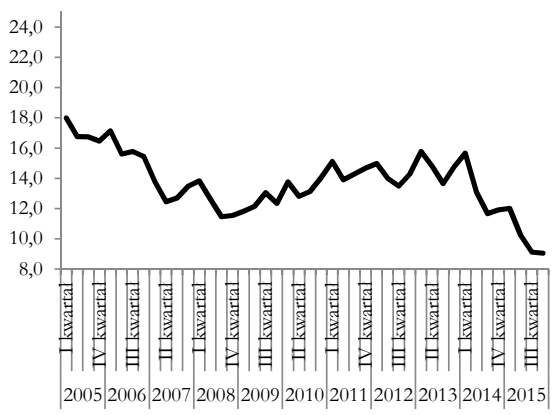

zachodniopomorskie

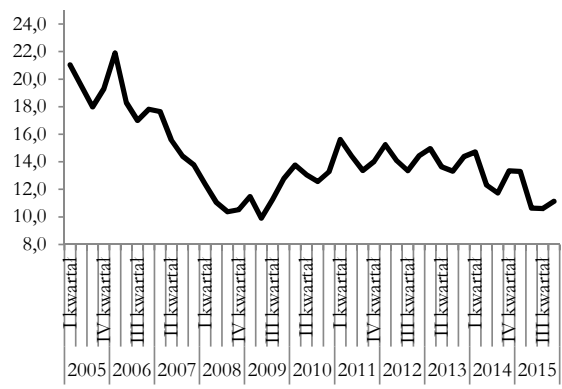

Źródło: opracowanie własne na podstawie: [www.stat.gov.pl, data wejścia: 11.03.2016].

Najwyższa średnia stóp bezrobocia wśród osób z wykształceniem policealnym i średnim zawodowym (województwo warmińsko-mazurskie) przekroczyła najwyższą średnią 
stóp bezrobocia wśród osób z wykształceniem wyższym o 6,46 p.p. Jednak nawet w tym województwie można zauważyć korzystny kierunek zmian badanego wská́nika. Najwyższa w badanym okresie stopa bezrobocia (23,65\% w I kwartale 2005 roku) w województwie warmińsko-mazurskim była 2,1 razy większa od najniższej (11,04\% w III kwartale 2015 roku). Natomiast różnica między wartością stopy bezrobocia na początku a wartością tego wskaźnika na końcu badanego okresu wyniosła 12,16 p.p. W innych województwach również spadek stóp bezrobocia w badanym okresie był znaczący średnio o 8,48 p.p. Najmniejsza różnica (4,92 p.p) wystąpiła w województwie podlaskim. W województwie tym po znacznym spadku wskaźnika w latach 2005--2008 (od $15,48 \%$ do $6,51 \%$ ) nastapił gwałtowny wzrost w latach 2009-2012 (do 13,11\%), po czym niewielki spadek w latach 2013-2015 (do 10,57\%). Oznacza to, że w województwie podlaskim zapotrzebowanie na pracowników z wykształceniem policealnym i średnim zawodowym nie wzrosła. Być może rynek pracy pod tym względem został nasycony i dlatego bezrobocie wśród tych osób od 2013 roku utrzymało się na poziomie $11-12 \%$. W pozostałych województwach różnice między maksymalną a minimalną wartością stopy bezrobocia były większe i wskaźnik ten malał. Ukończenie szkoły policealnej lub średniej zawodowej dało absolwentom konkretny zawód i pewne umiejętności oraz umoźliwiło uzyskanie dyplomu potwierdzającego posiadane kwalifikacje zawodowe. Malejąca stopa bezrobocia wśród bezrobotnych z konkretnymi kwalifikacjami wiązała się z tym, że na rynku pracy w województwach naszego kraju byli poszukiwani pracownicy z takim wykształceniem. W tej grupie bezrobotnych można było zarazem zauważyć sezonowe zmiany stopy bezrobocia, co świadczyło także o podejmowaniu prac sezonowych. Mimo to można było to wytłumaczyć posiadanym wykształceniem, z pewnością część tych osób posiadała zawód, na który było zwiększone zapotrzebowanie w pewnym sezonie, np.: w budownictwie, w gastronomii, w rolnictwie itp.

\subsection{Analiza stóp bezrobocia wśród osób z wykształceniem średnim ogólnokształcącym}

Stopy bezrobocia osób z wykształceniem średnim ogólnokształcącym w badanym okresie charakteryzowały się najbardziej stałym poziomem. Podobnie jak wśród innych kategorii, w latach 2005-2008 odnotowano spadki, a w latach 2009-2015 wzrost wskaźników we wszystkich województwach, choć zmiany te były nieznaczne. W dziesięciu województwach iloraz maksymalnej do minimalnej stopy bezrobocia był mniejszy niż 2. W sześciu województwach maksymalna stopa bezrobocia była ponad 2 razy większa od minimalnej w tym województwie. Największy stosunek maksymalnej do minimalnej stopy bezrobocia stwierdzono w województwie podlaskim.

Najwyższa w badanym okresie stopa bezrobocia $(17,21 \%$ w I kwartale 2013 roku) w tym województwie była 2,75 razy większa od najniższej (6,26\% w III kwartale 2008 roku). Jednakże w większości województw w latach 2005-2015 stopa bezrobocia wśród osób z wykształceniem średnim ogólnokształcącym nie zmieniła się znacząco i wyróżniała się prawie stałym poziomem. 
WYKRES 5. Najniższe stopy bezrobocia osób z wykształceniem średnim ogólnokształcącym w latach 2005-2015

łódzkie

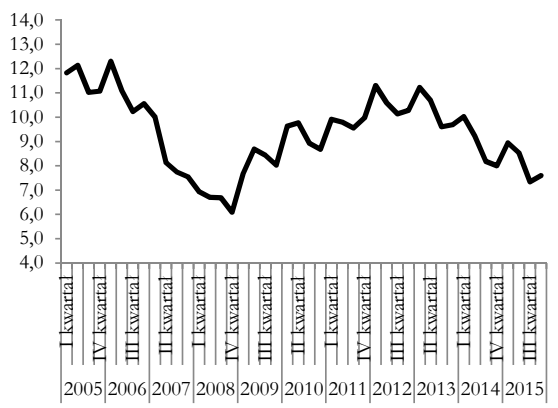

śląskie

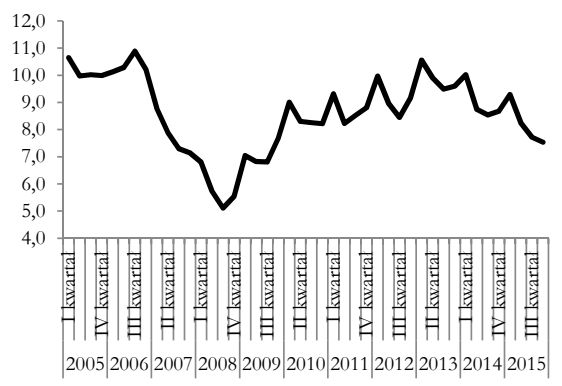

mazowieckie

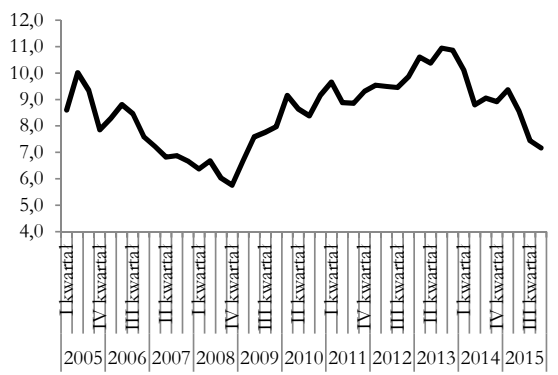

małopolskie

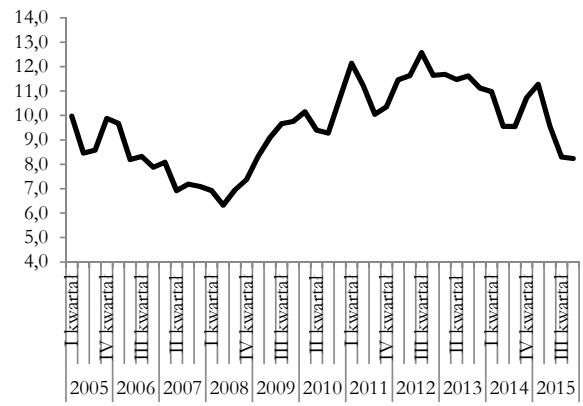

wielkopolskie

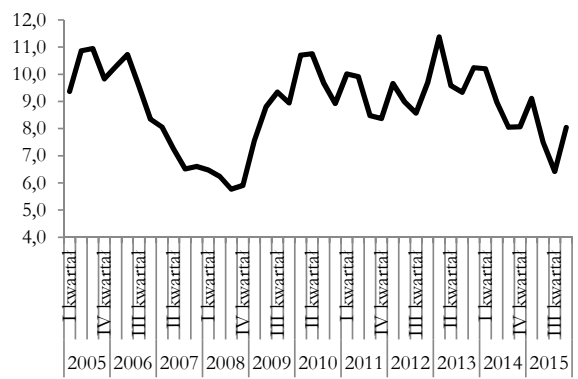

Źródło: opracowanie własne na podstawie: [www.stat.gov.pl, data wejścia: 11.03.2016].

Najniższa stopa bezrobocia wśród osób z tym wykształceniem w latach 2005-2007 (wykres 5.) występowała w województwach: mazowieckim (średnia: 8,04\%) i małopolskim (średnia: 8,35\%). 
Niewiele wyższa w tym okresie stopa bezrobocia była w województwie wielkopolskim (średnia: 9,03\%). Natomiast od roku 2008 najniższą stopę bezrobocia odnotowano w województwie śląskim (średnia: 8,62\%). Od III kwartału 2011 roku do III kwartału 2015 roku nieznacznie niższa była stopa bezrobocia w województwie wielkopolskim. Od 2009 roku można zauważyć wyraźny wzrost stopy bezrobocia w województwie małopolskim. W województwie tym najwyższa stopa bezrobocia $(12,57 \%$ w III kwartale 2012 roku) była 1,99 razy większa od najniższej (6,22\% w II kwartale 2008 roku) w badanym okresie.

Najwyższe stopy bezrobocia wśród osób z wykształceniem średnim ogólnokształcacym w analizowanym okresie (wykres 6.) stwierdzono w województwie świętokrzyskim (w latach 2005-2007 średnia stóp bezrobocia: 17,85\%) oraz warmińsko-mazurskim (od 2008 roku średnia stóp bezrobocia: 17,5\%).

WYKRES 6. Najwyższe stopy bezrobocia osób z wykształceniem średnim ogólnokształcącym w latach 2005-2015

warmińsko-mazurskie

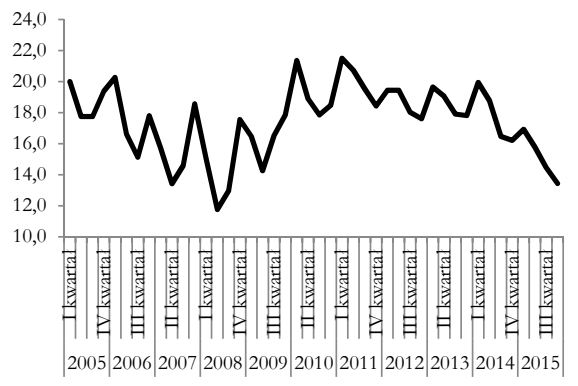

podkarpackie

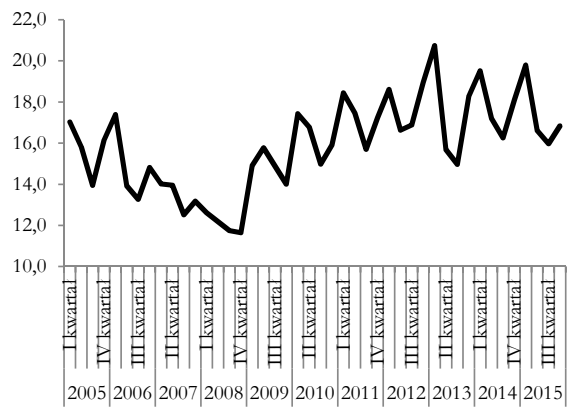

świętokrzyskie

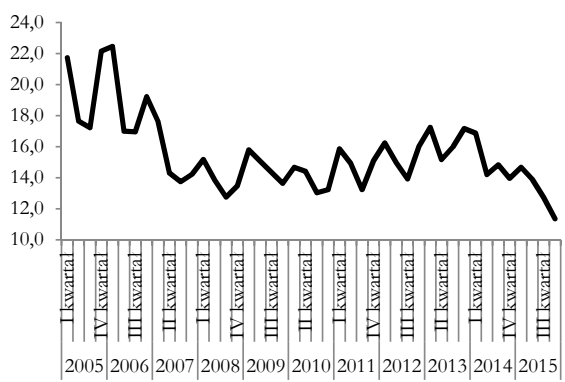

zachodniopomorskie

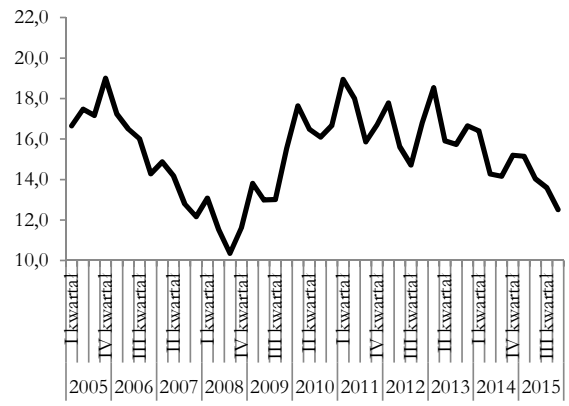

Źródło: opracowanie własne na podstawie: [www.stat.gov.pl, data wejścia: 11.03.2016].

W województwie warmińsko-mazurskim stopa bezrobocia znacząco przewyższyła wskaźniki w innych województwach, także można było zaobserwować występowanie 
zmian międzykwartałowych. W województwie tym nie było zapotrzebowania na pracowników z wykształceniem średnim ogólnokształcącym, więc osoby bezrobotne $z$ tym wykształceniem podejmowały prace sezonowe, np. związane z rolnictwem czy turystyką, gdyż te dziedziny gospodarki dominowały w województwie warmińsko-mazurskim. Od roku 2014 najwyższa stopa bezrobocia wśród osób z wykształceniem średnim ogólnokształcącym występowała w województwie podkarpackim. W województwie tym również występowały wahania międzykwartałowe. Jednak najwyższa w badanym okresie stopa bezrobocia (20,74\% w I kwartale 2013 roku) w tym województwie była 1,78 razy większa od najniższej (11,64\% w IV kwartale 2008 roku). Ponadto, mimo pewnych wzrostów i spadków stopy bezrobocia, różnica między wartością tego wskaźnika na początku i na końcu badanego okresu wyniosła tylko 0,19 p.p.

Takie zmiany stóp bezrobocia w badanym okresie wśród osób z wykształceniem średnim ogólnokształcącym prawdopodobnie wynikały z faktu, iż wykształcenie to nie dawało żadnych umiejętności zawodowych, więc większość absolwentów takich szkół podjęła studia wyższe. Dotyczyło to zwłaszcza ludzi młodych, którzy niedawno ukończyli kształcenie. Młodzi ludzie po skończeniu szkoły ogólnokształcącej najczęściej kontynuowali naukę. Osoby bezrobotne w tej grupie to przypuszczalnie osoby starsze, które wcześniej z różnych przyczyn nie zaistniały na rynku pracy (np.: wychowanie dzieci, prowadzenie domu) lub utraciły pracę (np. redukcja etatów) i bez wykształcenia wyższego (ani zawodowego), czyli bez konkretnych umiejętności, nie mogły znaleźć zatrudnienia.

\subsection{Analiza stóp bezrobocia wśród osób z wykształceniem zasadniczym zawodowym}

Stopy bezrobocia wśród osób z wykształceniem zasadniczym zawodowym były wyższe niż wśród wcześniej analizowanych rodzajów wykształcenia. Objęło to zwłaszcza lata 2005-2008, w których jednak odnotowano znaczący spadek analizowanych wskaźników. Od roku 2009 można było zauważyć wzrost stóp bezrobocia, lecz nie tak duży, jak wcześniejszy spadek. Najniższa stopa bezrobocia występowała w województwach: śląskim, wielkopolskim, małopolskim i łódzkim (wykres 7.). Najniższa średnia stóp bezrobocia (9,53\%) miała miejsce w województwie śląskim, ale w tym województwie nastąpiła także bardzo duża zmienność (współczynnik zmienności: ponad 26\%). Można stwierdzić, że wśród osób z wykształceniem zasadniczym zawodowym współczynniki zmienności były dużo wyższe niż wśród wcześniej analizowanych rodzajów wykształcenia. Świadczy to o zwiększonym zapotrzebowaniu na pracowników z takim wykształceniem do prac sezonowych, np. w: budownictwie, turystyce czy rolnictwie.

Najwyższe stopy bezrobocia w prawie całym badanym okresie (poza latami 20072008) pojawiły się w województwie warmińsko-mazurskim (średnia: ponad 20\%) (wykres 8.). Jednocześnie wysokie były w zachodniopomorskim, a od 2008 roku w podkarpackim. Sa to województwa o niskim stopniu uprzemysłowienia, typowo rolnicze, w których rynek pracy jest słabo rozwinięty. Z tego powodu odnotowano w nich najwyższe stopy bezrobocia niezależnie od wykształcenia. 
WYKRES 7.

\section{Najniższe stopy bezrobocia osób z wykształceniem zasadniczym zawodowym w latach 2005-2015}

śląskie

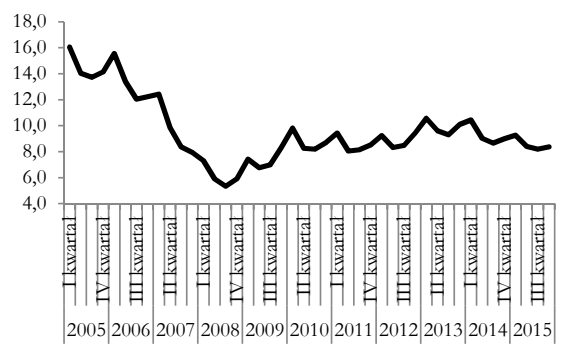

łódzkie

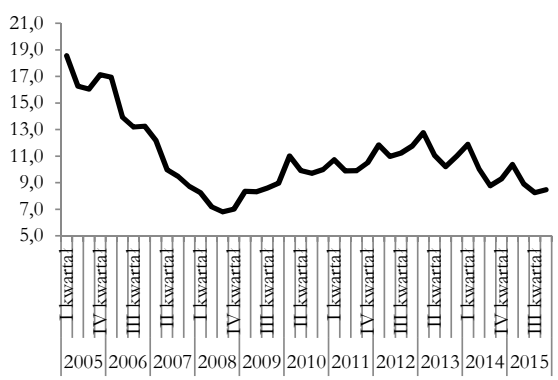

wielkopolskie

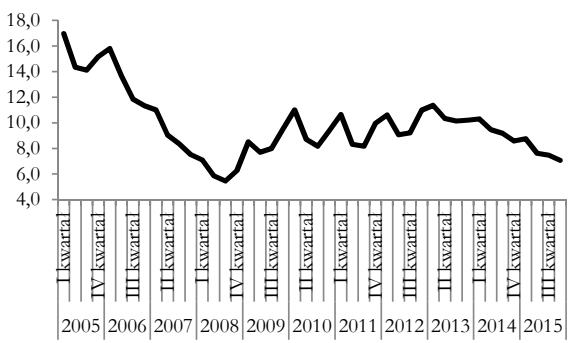

małopolskie

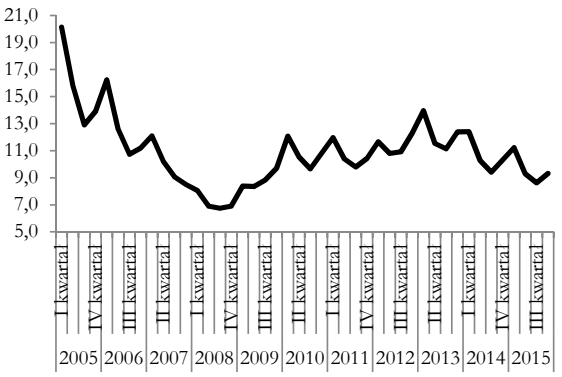

Źródło: opracowanie własne na podstawie: [www.stat.gov.pl, data wejścia: 11.03.2016].

Stopy bezrobocia wśród osób z wykształceniem zasadniczym zawodowym wyraźnie zmniejszyły się w badanym okresie. Przykładowo w województwie z najniższą średnią stóp bezrobocia, czyli w województwie śląskim, różnica między wartością tego wskaźnika na początku i na końcu badanego okresu wynosiła 7,69 p.p., a najwyższa w badanym okresie stopa bezrobocia (16,06\% w I kwartale 2005 roku) w tym województwie była aż 3,01 razy większa od najniższej (5,33\% w III kwartale 2008 roku). Natomiast w województwie z najwyższą średnią, czyli w województwie warmińsko-mazurskim, różnica między wartością tego wskaźnika na początku i na końcu badanego okresu stanowiła aż 18,14 p.p., a najwyższa w badanym okresie stopa bezrobocia $(31,73 \%$ w I kwartale 2005 roku) w tym województwie była 2,45 razy większa od najniższej (12,93\% w III kwartale 2008 roku). Korzystne zmiany stóp bezrobocia świadczą o rosnącym popycie na pracowników $z$ wykształceniem zasadniczym zawodowym, czyli na osoby posiadające pewne kwalifikacje zawodowe. 
WYKRES 8. Najwyższe stopy bezrobocia osób z wykształceniem zasadniczym zawodowym w latach 2005-2015

warmińsko-mazurskie

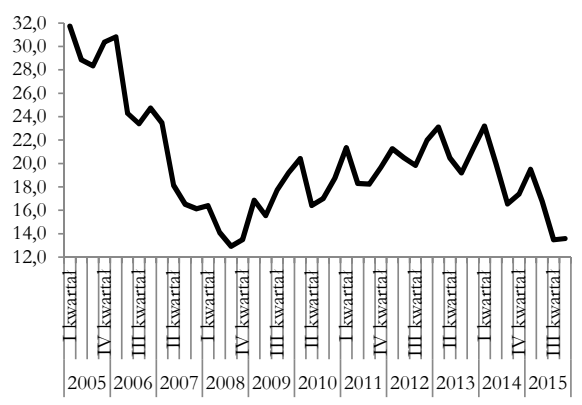

podkarpackie

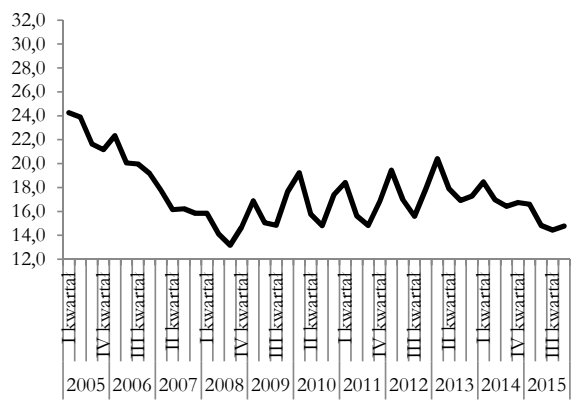

Źródło: opracowanie własne na podstawie: [www.stat.gov.pl, data wejścia: 11.03.2016].

\subsection{Analiza stóp bezrobocia wśród osób z wykształceniem gimnazjalnym, podstawowym i niepełnym podstawowym}

Wśród osób z wykształceniem gimnazjalnym, podstawowym i niepełnym podstawowym w latach 2005-2015 występowała najwyższa stopa bezrobocia w porównaniu z innymi kategoriami wykształcenia. Osoby z takim wykształceniem można uznać za osoby bez wykształcenia, gdyż nie posiadają one nawet podstawowych umiejętności, które można zdobyć w szkole zasadniczej zawodowej, a więc zapotrzebowanie na ich pracę jest znikome.

Najniższa średnia stóp bezrobocia $(13,86 \%)$ wśród tych osób pojawiła się w województwie małopolskim, zaś najwyższa (29,51\%) w województwie zachodniopomorskim. W całym badanym okresie najniższa stopa bezrobocia miała miejsce w województwie małopolskim (wykres 9.), a od 2009 roku podobna w województwie wielkopolskim (średnia: 15,28\%). W województwie z najniższą średnią, czyli w województwie mało- 
polskim, różnica między wartością tego wskaźnika na początku i na końcu badanego okresu wynosiła tylko 3,43 p.p., a najwyższa w badanym okresie stopa bezrobocia (18,78\% w IV kwartale 2012 roku) w tym województwie była 2,24 razy większa od najniższej (8,37\% w III kwartale 2008 roku).

WYKRES 9.

Najniższe stopy bezrobocia osób z wykształceniem gimnazjalnym, podstawowym i niepełnym podstawowym w latach 2005-2015

małopolskie

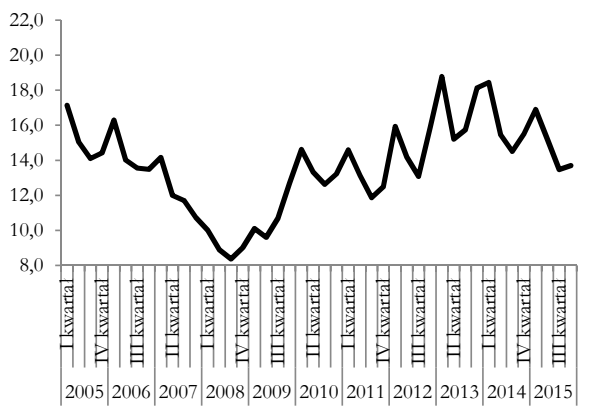

wielkopolskie

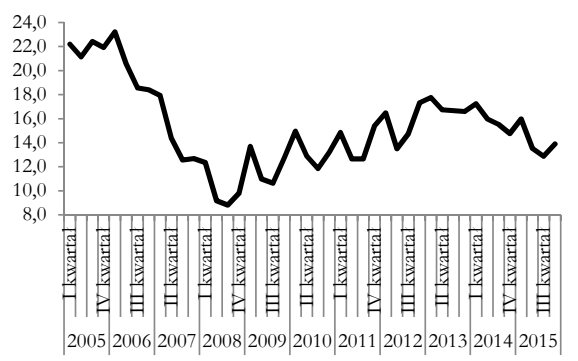

świętokrzyskie

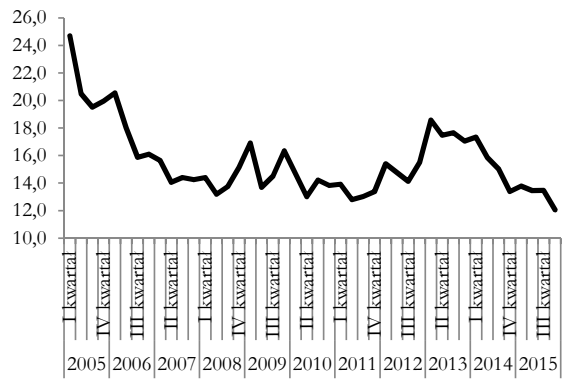

podlaskie

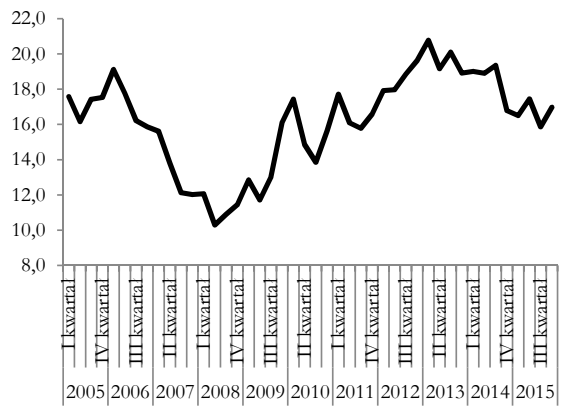

lubelskie

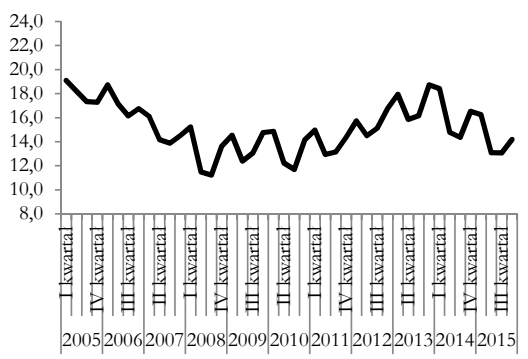

Źródło: opracowanie własne na podstawie: [www.stat.gov.pl, data wejścia: 11.03.2016]. 
Pokazuje to mało korzystne zmiany wśród bezrobotnych z takim wykształceniem. W'śód województw z niską stopą bezrobocia w tej kategorii wykształcenia znalazły się również województwa: podlaskie ('́rednia: 16,18\%), lubelskie (średnia: 15,13\%), a także świętokrzyskie (średnia: 15,57\%). Są to województwa o stosunkowo niskim poziomie rozwoju, położone na wschodniej ścianie Polski, w których nie ma rozwiniętych szczególnie innowacyjnych gałęzi przemysłu. Rozwijają się w nich głównie: rolnictwo, turystyka oraz małe rodzinne przedsiębiorstwa, w których łatwiej odnaleźć się osobom z tak niskim wykształceniem. Dlatego też w województwach tych sytuacja na rynku pracy osób z wykształceniem gimnazjalnym, podstawowym i niepełnym podstawowym kształtowała się inaczej niż osób np. z wykształceniem wyższym. Stopy bezrobocia $z$ wykształceniem wyższym w tych województwach były najwyższe w Polsce w badanym okresie.

WYKRES 10.

Najwyższe stopy bezrobocia osób z wykształceniem gimnazjalnym, podstawowym i niepełnym podstawowym w latach 2005-2015

zachodniopomorskie

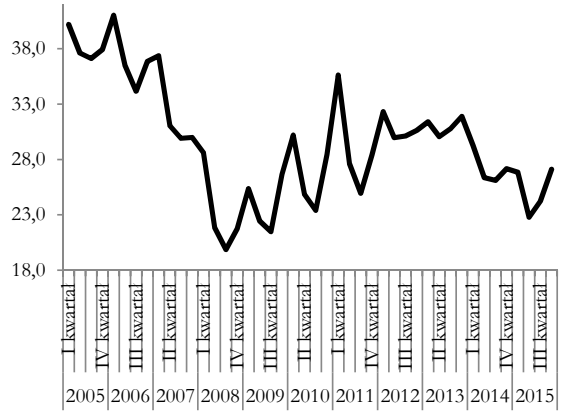

dolnośląskie

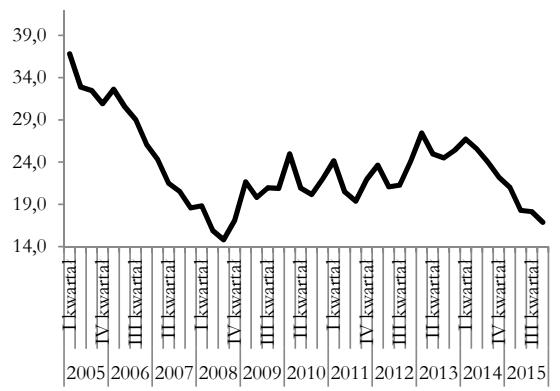

warmińsko-mazurskie

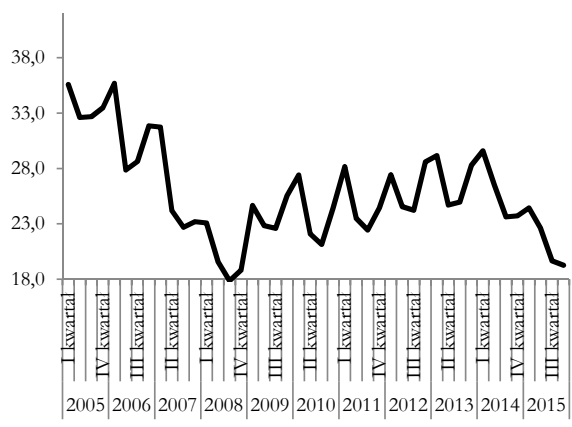

kujawsko-pomorskie

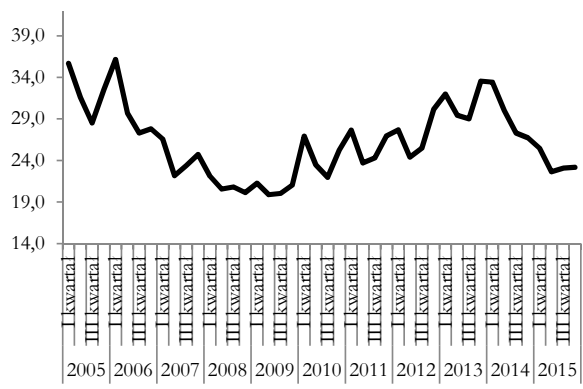

Źródło: opracowanie własne na podstawie: [www.stat.gov.pl, data wejścia: 11.03.2016]. 
Najwyższe stopy bezrobocia wśród osób z analizowanym wykształceniem w badanym okresie występowały w województwie zachodniopomorskim (średnia: 29,51\%), a od roku 2013 w kujawsko-pomorskim (średnia: 26,27\%) (wykres 10.). Wysokie bezrobocie zaobserwowano również w województwie warmińsko-mazurskim (średnia: 25,69\%) oraz województwie dolnośląskim (średnia: 23,31\%). Stopy bezrobocia w tej kategorii wykształcenia charakteryzowały się dość wysoką zmiennością, co potwierdziło tezę, że osoby „,bez wykształcenia” znajdowały zatrudnienie przy pracach sezonowych, niewymagających konkretnych kwalifikacji.

Podobnie jak w pozostałych kategoriach wykształcenia, w latach 2005-2008 odnotowano znaczący spadek stóp bezrobocia, a w kolejnych latach wzrost, jednak mniejszy niż wcześniejszy spadek.

Dzięki temu wskaźniki te na koniec badanego okresu były niższe niż na początku (tabela 1.).

TABELA 1.

Średnie stóp bezrobocia osób z wykształceniem: gimnazjalnym, podstawowym i niepełnym podstawowym w roku 2005 i roku 2015 (w \%)

\begin{tabular}{|l|c|c|}
\hline \multicolumn{1}{|c|}{ Rok } & $\mathbf{2 0 0 5}$ & $\mathbf{2 0 1 5}$ \\
\hline I kwartał & 27,70 & 19,64 \\
\hline II kwartał & 25,21 & 17,55 \\
\hline III kwartał & 25,26 & 16,74 \\
\hline IV kwartał & 25,69 & 17,11 \\
\hline
\end{tabular}

Źródło: opracowanie własne na podstawie: [www.stat.gov.pl, data wejścia: 11.03.2016].

\subsection{Taksonomiczna analiza stóp bezrobocia w województwach Polski}

$\mathrm{Na}$ podstawie obliczonych zgodnie $\mathrm{z}$ zaproponowaną metodologia stóp bezrobocia wśród osób według ich wykształcenia dokonano klasyfikacji województw Polski w grupy o podobnym kształtowaniu się poziomu tego wskaźnika. Wykorzystano kostkę danych zawierająca współczynniki bezrobocia obserwowane $\mathrm{w}$ trzech wymiarach, takich jak: poziom wykształcenia osób (5 kategorii), województwo (16 jednostek) oraz czas (44 kwartały). Zatem dla każdego województwa danych było 220 obserwacji współczynników bezrobocia ( 5 poziomów wykształcenia $\times 44$ kwartały).

Zastosowana została aglomeracyjna metoda taksonomiczna - metoda Warda z odległością euklidesowa. Metoda ta należy do metod hierarchicznych, czyli prowadzi od podziału na jednoelementowe klasy obiektów (województw) do jednej klasy zawierajacej wszystkie obiekty [szerzej: Pociecha, Podolec, Sokołowski Zając, 1988, s. 76 i nast.]. Graficzna prezentacją tego procesu jest dendogram (tzw. drzewko połączeń) (wykres 11.). 
$\mathrm{Na}$ podstawie dendrogramu (wykres 11.) 16 województw Polski podzielono na 4 grupy (tabela 2.) województw podobnych pod względem kształtowania się wskaźników bezrobocia wśród osób posiadających poszczególne poziomy wykształcenia.

W pierwszej grupie, poza województwem mazowieckim, znalazły się województwa z Polski Centralnej, tj:: łódzkie, wielkopolskie, a także Południowej, a mianowicie: śląskie i małopolskie (rysunek 1.). Są to rejony o wysokim stopniu rozwoju i stosunkowo niskim bezrobociu. Wśród bezrobotnych z wykształceniem: wyższym, policealnym i średnim zawodowym, średnim ogólnokształcącym oraz zasadniczym zawodowym w tych właśnie województwach odnotowano najniższe kwartalne wartości w latach 2005-2015. Zaistniało w nich niewielkie zapotrzebowanie na pracowników bez kwalifikacji, czyli z wykształceniem: gimnazjalnym, podstawowym i niepełnym podstawowym. Wśród województw o najniższych stopach bezrobocia w tej kategorii wykształcenia znalazły się jedynie województwa: małopolskie i wielkopolskie.

WYKRES 11.

Grupowanie województw o podobnym kształtowaniu się stóp bezrobocia, według wykształcenia bezrobotnych (dendrogram)

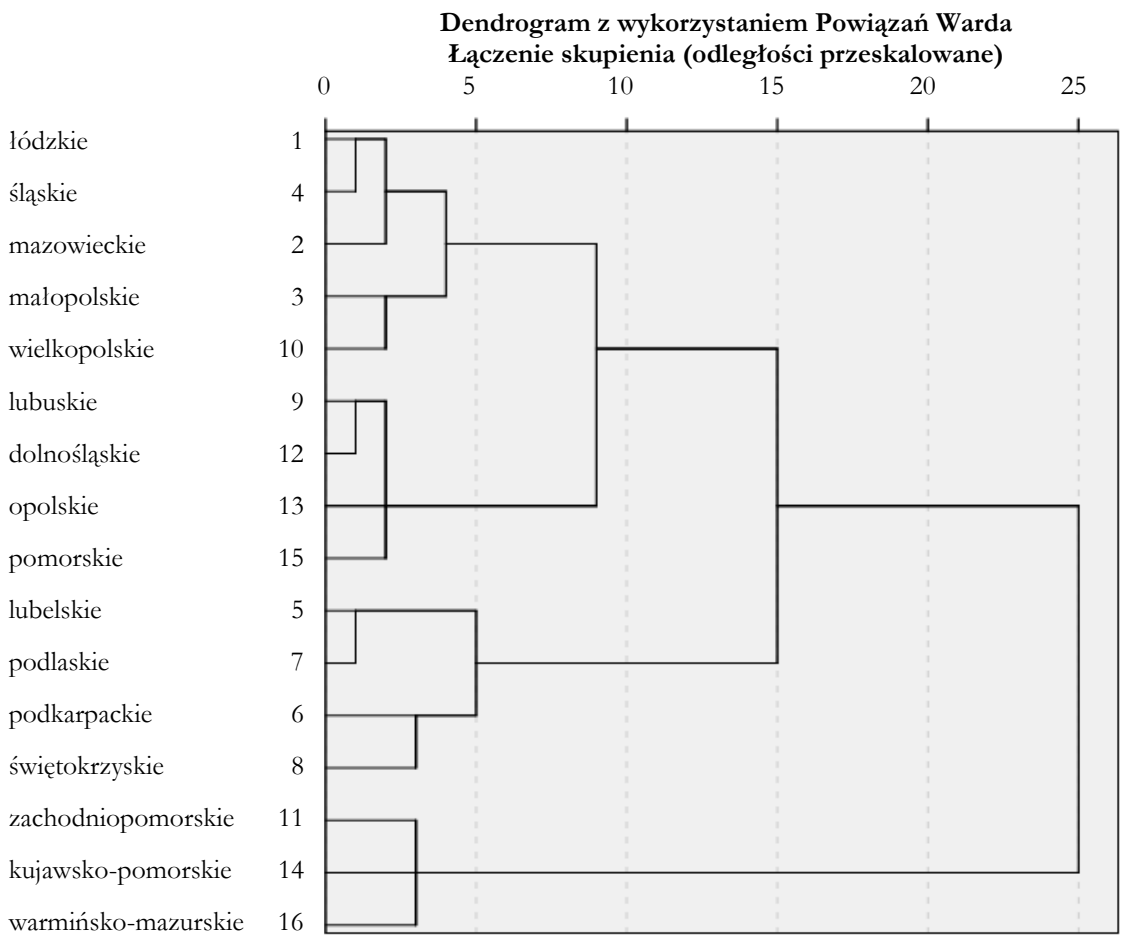

Źródło: opracowanie własne na podstawie: [www.stat.gov.pl, data wejścia: 11.03.2016].

W drugiej grupie znalazły się województwa z Polski Zachodniej, tj.: lubuskie, dolnośląskie, opolskie oraz województwo pomorskie (rysunek 1.). W województwach tych odnotowano przeciętne stopy bezrobocia we wszystkich kategoriach wykształcenia. 
Województwo pomorskie pojawiło się w grupie województw o niskich stopach bezrobocia wśród osób z wykształceniem wyższym. Natomiast w województwie dolnośląskim odnotowano wysokie stopy bezrobocia wśród osób z wykształceniem: gimnazjalnym, podstawowym i niepełnym podstawowym.

W trzeciej grupie znalazły się województwa Polski Wschodniej, takie jak: podlaskie, lubelskie, podkarpackie i województwo świętokrzyskie (rysunek 1.), czyli województwa o wysokich stopach bezrobocia. W województwach: lubelskim, podkarpackim, świętokrzyskim stwierdzono najwyższe stopy bezrobocia wśród osób z wykształceniem wyższym. W województwach tych znalazły się uczelnie wyższe, które kształciły więcej absolwentów z wyższym wykształceniem niż istniał popyt na rynku pracy. W województwach podkarpackim i świętokrzyskim były najwyższe stopy bezrobocia wśród osób z wykształceniem: policealnym i średnim zawodowym oraz ogólnokształcącym, a z wykształceniem zawodowym najwyższe wartości analizowanego wskaźnika były wśród osób z wykształceniem zasadniczym zawodowym. Co ciekawe, w województwach: lubelskim, podlaskim, świętokrzyskim zaobserwowano najniższe stopy bezrobocia wśród osób z wykształceniem: gimnazjalnym, podstawowym i niepełnym podstawowym. Można więc przypuszczać, że w rejonach o charakterze rolniczym, nastawionym na rozwój turystyki i produkcji rolnej, istnieje zapotrzebowanie na pracowników z najniższymi kwalifikacjami.

TABELA 2.

Podział województw na grupy o podobnym kształtowaniu się stóp bezrobocia, według wykształcenia bezrobotnych

\begin{tabular}{|c|l|}
\hline Grupa & Województwo \\
\hline \multirow{4}{*}{ I } & lódzkie \\
\cline { 2 - 3 } & śląskie \\
\cline { 2 - 3 } & mazowieckie \\
\cline { 2 - 3 } & małopolskie \\
\cline { 2 - 3 } & wielkopolskie \\
\hline \multirow{4}{*}{ II } & lubuskie \\
\cline { 2 - 3 } & dolnośląskie \\
\cline { 2 - 3 } & opolskie \\
\cline { 2 - 2 } & pomorskie \\
\hline \multirow{4}{*}{ III } & lubelskie \\
\cline { 2 - 3 } & podlaskie \\
\cline { 2 - 3 } & podkarpackie \\
\cline { 2 - 2 } & świętokrzyskie \\
\hline \multirow{3}{*}{ IV } & zachodniopomorskie \\
\cline { 2 - 2 } & kujawsko-pomorskie \\
\cline { 2 - 2 } & warmińsko-mazurskie \\
\hline
\end{tabular}

Źródło: opracowanie własne na podstawie: [www.stat.gov.pl, data wejścia: 11.03.2016]. 
W grupie czwartej znalazły się województwa, takie jak: zachodniopomorskie, warmińsko-mazurskie i kujawsko-pomorskie (rysunek 1.). Województwa zachodniopomorskie oraz warmińsko-mazurskie charakteryzowały się najwyższymi stopami bezrobocia we wszystkich kategoriach wykształcenia w badanym okresie. Dodatkowo wśród województw o najwyższych stopach bezrobocia wśród osób z wykształceniem: policealnym i średnim zawodowym oraz wykształceniem: gimnazjalnym, podstawowym i niepełnym podstawowym również znalazło się województwo kujawsko-pomorskie. Żadne z województw czwartej grupy nie pojawiło się wśród województw z najniższymi stopami bezrobocia w żadnej kategorii wykształcenia. W województwach tych nie było miejsc pracy dla bezrobotnych (niezależnie od wykształcenia).

RYSUNEK 1.

\section{Grupowanie województw o podobnym kształtowaniu się stóp bezrobocia, według wykształcenia}

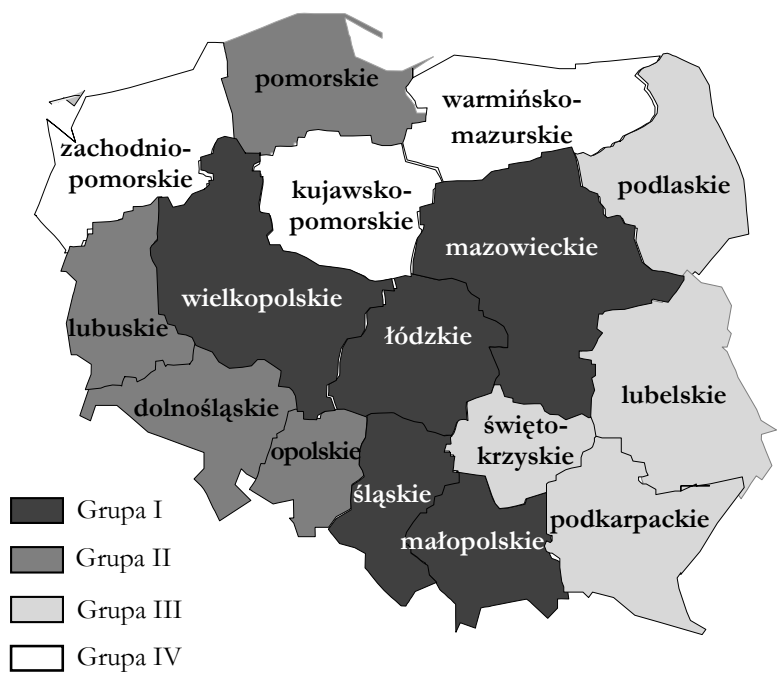

Źródło: opracowanie własne na podstawie: [www.stat.gov.pl, data wejścia: 11.03.2016].

\section{Podsumowanie}

Przeprowadzone badania objęły kolejne kwartały lat 2005-2015. Obliczono stopy bezrobocia w województwach Polski wśród osób z wyróżnionymi poziomami wykształcenia, a mianowicie: wyższe, policealne oraz średnie zawodowe, średnie ogól- 
nokształcące, zasadnicze (zawodowe) i gimnazjalne, podstawowe oraz niepełne podstawowe.

Podsumowując wyniki tych badań, można sformułować poniższe wnioski.

WYKRES 12.

Średnie arytmetyczne wojewódzkich stóp bezrobocia w poszczególnych kwartałach, w latach 2005-2015 wśród osób posiadających poszczególne poziomy wykształcenia

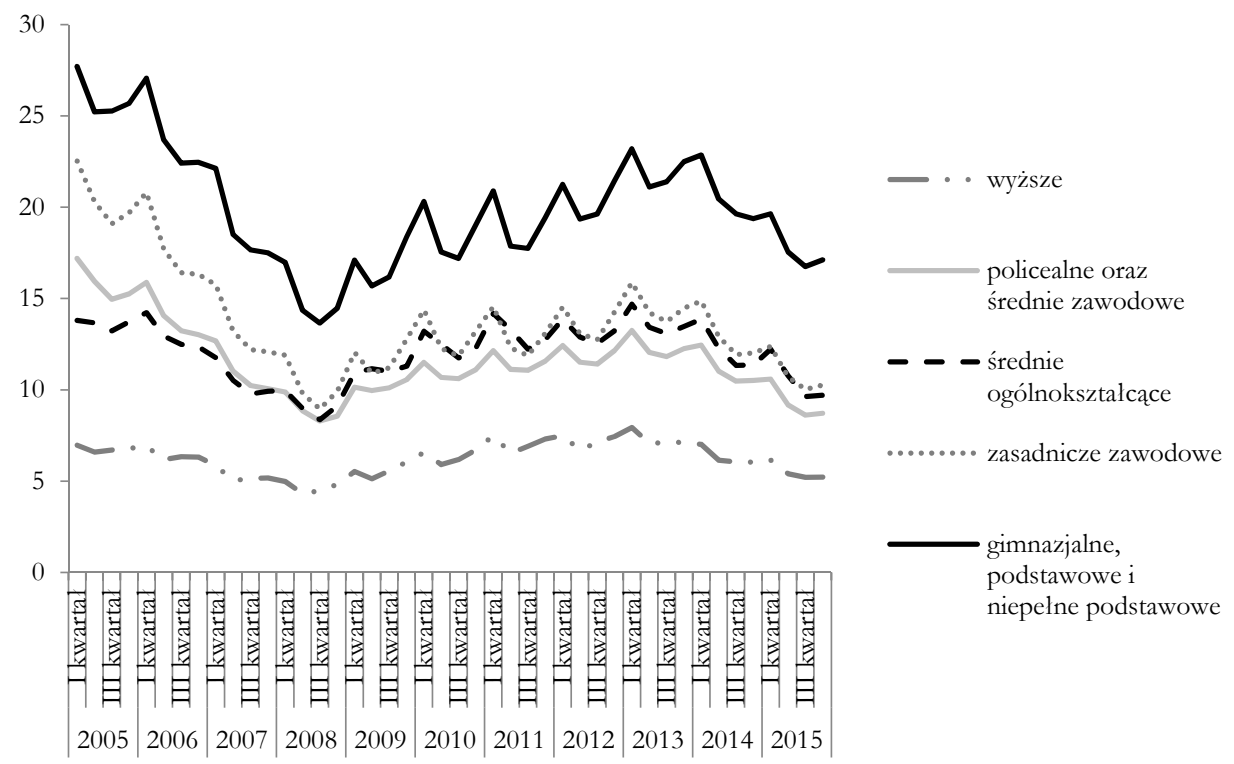

Źródło: opracowanie własne na podstawie: [www.stat.gov.pl, data wejścia: 11.03.2016].

1. W latach 2005-2008 średnie arytmetyczne kwartalnych stóp bezrobocia w województwach Polski, niezależnie od wykształcenia bezrobotnych, malały, osiagając swój najniższy poziom w III kwartale roku 2008 (wykres 12.). W tym okresie średnie stóp bezrobocia wśród bezrobotnych z wykształceniem: gimnazjalnym, podstawowym i niepełnym podstawowym kształtowały się prawie identycznie jak średnie stóp bezrobocia wśród bezrobotnych z wykształceniem zasadniczym (zawodowym). Największa różnica między nimi była w I kwartale 2005 roku i wynosiła 3,07 p.p. Jednak były to najwyższe średnie stóp bezrobocia wśród wszystkich analizowanych w tym okresie. Można więc stwierdzić, że w latach 2005-2008 im wyższe wykształcenie miał poszukujący pracy, tym większa była szansa na jej znalezienie. W związku z tym, im więcej lat poświęcono na edukację, tym niższe były stopy bezrobocia. Natomiast średnie stóp bezrobocia wśród bezrobotnych z wykształceniem: gimnazjalnym, podstawowym i niepełnym podstawowym w tym okresie były zdecydowanie najwyższe i przewyższały omówione wskaźniki wśród bezrobotnych z wykształceniem zasadniczym zawodowym o około 5 p.p. Najniższe średnie stóp bez- 
robocia zaobserwowano wśród osób z wykształceniem wyższym, ponadto wskaźniki te najmniej zmieniały się w latach $2005-2008$, prezentując prawie stały poziom.

2. W latach 2009-2013 średnie arytmetyczne wojewódzkich stóp bezrobocia w Polsce rosły niezależnie od wykształcenia (wykres 12.). Nadal najniższe były średnie stóp bezrobocia wśród osób z wykształceniem wyższym, ich wzrost również w tych latach nie był zbyt duży. Gwałtownie wzrosła średnia stóp bezrobocia wśród osób z wykształceniem średnim ogólnokształcącym. Jej wartości zbliżyły się do średnich stóp bezrobocia w grupie bezrobotnych z wykształceniem zasadniczym (zawodowym), nawet je przekraczając w II i III kwartale 2011 roku. Średnie te były wyższe od średnich stóp bezrobocia osób z wykształceniem policealnym i średnim zawodowym. Przykładowo różnica między nimi w I kwartale 2011 roku wynosiła ponad 2 p. p. (warto zauważyć, że na koniec 2008 roku miały one bardzo zbliżone wartości). W okresie tym znacząco wzrosły także średnie stóp bezrobocia wśród osób z wykształceniem: gimnazjalnym, podstawowym i niepełnym podstawowym. Jak już wspomniano wcześniej, tak duży wzrost analizowanych współczynników w grupach z wykształceniem: gimnazjalnym, podstawowym i niepełnym podstawowym oraz średnim ogólnokształcącym $z$ jednoczesnym mniejszym wzrostem stóp w grupach $\mathrm{z}$ wykształceniem zasadniczym (zawodowym) i policealnym oraz średnim zawodowym świadczy o wzroście ofert pracy dla osób posiadających pewne kwalifikacje zawodowe, a niewielkiej liczbie ofert pracy dla osób nieposiadających takich kwalifikacji.

3. Od I kwartału 2014 roku średnie arytmetyczne wojewódzkich stóp bezrobocia w poszczególnych kwartałach, niezależnie od wykształcenia bezrobotnych, malały (wykres 12.). Jednak spadki te były znacznie mniejsze niż w początkowym badanym okresie (2005-2008). Zachowane zostały zależności między wskaźnikami, czyli najwyższe stopy bezrobocia odnotowano wśród osób bezrobotnych z wykształceniem: gimnazjalnym, podstawowym i niepełnym podstawowym i były one znacząco większe niż w pozostałych grupach. Zbliżone wartości wskaźnika zaobserwowano wśród osób z wykształceniem: zasadniczym zawodowym, średnim ogólnokształcącym i policealnym oraz średnim zawodowym. Najniższe zaś były wśród osób z wykształceniem wyższym.

4. Średnie arytmetyczne wojewódzkich stóp bezrobocia w Polsce, w latach 2005-2015 wyróżniały się sezonowością, w I i IV kwartałach każdego roku były wyższe niż w II i III kwartałach danego roku (wykres 12.). Natomiast I i IV kwartał roku to okres jesienno-zimowy. W tym czasie znacząco zmniejszył się popyt na pracowników w takich działach gospodarki, jak np.: budownictwo, rolnictwo, turystyka. Zastanawiający jest wpływ sezonowości na średnie stóp bezrobocia wśród osób z wykształceniem wyższym. Jak już wzmiankowano, może to przemawiać za podejmowaniem przez te osoby prac sezonowych, czyli prawdopodobnie poniżej ich kwalifikacji zawodowych. Wynika stąd wniosek, że zbyt mało jest ofert dla absolwentów wyższych uczelni na polskim rynku pracy. Tak wiele działających wyższych uczelni (publicz- 
nych i niepublicznych) oraz stosunkowo niski rozwój gospodarki generuje w naszym kraju liczne grono bezrobotnych z wykształceniem wyższym. Jednak biorąc pod uwagę fakt, że stopy bezrobocia wśród osób z wyższym wykształceniem były niższe od stóp w innych kategoriach wykształcenia w całym badanym okresie, skończenie studiów wyższych nadal daje największe szanse na znalezienie pracy.

5. Najniższe średnie arytmetyczne wojewódzkich stóp bezrobocia w analizowanym okresie były w II/III kwartale 2008 roku (wykres 12.). Od tego momentu obserwowano spowolnienie wzrostu gospodarczego, czego skutkiem był wzrost bezrobocia wśród wszystkich analizowanych grup. Jednocześnie w Polsce II i III kwartał to pory roku, w których pojawiały się prace sezonowe, przy których rokrocznie wielu bezrobotnych znajdowało zatrudnienie. Co ciekawe, mimo że w III kwartale każdego roku na rynku pracy znaleźli się absolwenci (na każdym poziomie kształcenia), w tym właśnie okresie średnie stóp bezrobocia w badanych grupach były najniższe (w roku 2008), jedynie w grupie bezrobotnych z wykształceniem wyższym najniższa średnia stóp bezrobocia była w II kwartale. Pozytywnie świadczy to o wspomnianych młodych ludziach, którzy po skończeniu edukacji (niezależnie od poziomu) potrafili odnaleźć się na rynku pracy, choć często było to zatrudnienie sezonowe, bez możliwości kontynuowania w IV kwartale roku.

6. Najwyższe średnie arytmetyczne wojewódzkich stóp bezrobocia dla osób z wykształceniem: policealnym oraz średnim zawodowym, zasadniczym zawodowym, a także gimnazjalnym, podstawowym i niepełnym podstawowym były w I kwartale 2005 roku (wykres 12.). Zatem, wbrew wzrostowi średnich stóp po roku 2008 na koniec badanego okresu, analizowane współczynniki nie osiagnęły swoich poziomów z okresu początkowego. Można więc prognozować korzystne trendy dla osób z tym właśnie wykształceniem, czyli w większości posiadających kwalifikacje zawodowe. Natomiast dla osób z wykształceniem wyższym i średnim ogólnokształcącym najwyższe stopy bezrobocia były w I kwartale 2013 roku. Wartości analizowanego współczynnika na koniec badanego okresu były jednak niższe niż ich początkowe wielkości (tabela 3.). O ile nie dziwi taki niewielki spadek bezrobocia wśród osób z wykształceniem średnim ogólnokształcącym, czyli bez konkretnych kwalifikacji zawodowych, gdyż nie sa to pracownicy poszukiwani na rynku pracy, zastanawiający i niekorzystny jest tak mały spadek bezrobocia wśród absolwentów wyższych uczelni w latach 2005-2015. Mimo że ciagle w tej grupie bezrobocie jest najniższe, to jeśli taki niekorzystny trend się utrzyma, sytuacja może ulec zmianie. 
TABELA 3. Średnie stóp bezrobocia w województwach Polski, w I kwartale 2005 i 2015 roku (w \%) oraz ich różnice

\begin{tabular}{|l|c|c|c|}
\hline \multirow{2}{*}{ Wykształcenie } & \multicolumn{2}{|c|}{ I kwartał } & \multirow{2}{*}{ Różnica (p.p.) } \\
\cline { 2 - 3 } & $\mathbf{2 0 0 5}$ & $\mathbf{2 0 1 5}$ & \\
\hline Wyższe & 6,97 & 6,16 & $-0,81$ \\
\hline Policealne oraz średnie zawodowe & 17,20 & 10,59 & $-6,61$ \\
\hline Średnie ogólnokształcące & 13,81 & 12,23 & $-1,58$ \\
\hline Zasadnicze zawodowe & 22,53 & 12,38 & $-10,15$ \\
\hline $\begin{array}{l}\text { Gimnazjalne, podstawowe i niepełne podsta- } \\
\text { wowe }\end{array}$ & 27,70 & 19,64 & $-8,06$ \\
\hline
\end{tabular}

Źródło: opracowanie własne na podstawie: [www.stat.gov.pl, data wejścia: 11.03.2016].

7. Najwyższa średnia arytmetyczna ze średnich wojewódzkich stóp bezrobocia w województwach Polski w badanym okresie wynosiła 19,89\% i dotyczyła osób z wykształceniem: gimnazjalnym, podstawowym i niepełnym podstawowym. Biorąc pod uwagę ten fakt oraz znacząco wyższe średnie stopy bezrobocia w tej grupie osób w całym badanym okresie, można stwierdzić, że zakończenie edukacji na tak niskim poziomie dyskwalifikuje takie osoby na rynku pracy. Wysoka była również średnia wśród osób z wykształceniem zasadniczym zawodowym - 13,76\%. Jednak uwzględniając korzystny kierunek zmian bezrobocia w tej grupie (od I kwartału 2005 roku do I kwartału roku 2015 zmalała o 10,15 p.p.), można skonstatować, że nieustannie jest popyt na pracowników słabo wykształconych, lecz posiadających pewne umiejętności. Średnie stóp bezrobocia wśród osób z wykształceniem średnim ogólnokształcącym i policealnym oraz średnim zawodowym stanowiły odpowiednio: 12,05\% i 11,55\%. Mimo że różniły się one o mniej niż 1 p.p., w grupach tych zaobserwowano odmienne tendencje zmian. Liczba bezrobotnych z wykształceniem średnim ogólnokształcącym prawie nie zmieniła się na przestrzeni ostatnich 11 lat, w przeciwieństwie do większości innych kategorii wykształcenia, gdzie stopy bezrobocia zmalały. Oznacza to, że zakończenie edukacji na etapie maturalnym jest zdecydowanie niewystarczające, by odnaleźć się na rynku pracy. Natomiast stopa bezrobocia wśród osób z wykształceniem policealnym i średnim zawodowym znacznie zmalała, co pozwala sformułować konkluzję, że bezrobotni z takim wykształceniem mają szansę, aby zaistnieć na rynku pracy i jeśli zaobserwowana tendencja utrzyma się, ich sytuacja może nawet poprawić się. Najniższa średnia arytmetyczna ze średnich wojewódzkich stóp bezrobocia w badanym okresie wynosiła 6,23\% i dotyczyła osób z wykształceniem wyższym. Jeżeli uwzględnić niekorzystny, niewielki spadek tych współczynników w badanych latach, można przypuszczać, że jeśli gospodarka Polski nie zacznie gwałtownie rozwijać się, bezrobotnych z wykształceniem wyższym będzie przybywać. Istnieje także duże prawdopodobieństwo, że absolwenci dobrze wykształceni 
przez polskie uczelnie będą poszukiwać zatrudnienia w innych województwach lub poza granicami kraju.

8. Można zauważyć, że województwa o podobnym kształtowaniu się stóp bezrobocia według wykształcenia są często położone obok siebie (rysunek 1.). Pierwszą grupę stanowiły województwa leżące w centralnej (i dwa w południowej) części kraju o stosunkowo niskich stopach bezrobocia. Druga grupę objęły województwa zachodnie (i jedno północne) o przeciętnych stopach bezrobocia. Grupa trzecia to województwa wschodnie o dość wysokich wartościach badanego wskaźnika, zaś czwarta - północne (bez pomorskiego), w których odnotowano najwyższe stopy bezrobocia niezależnie od wykształcenia. Wynika to z faktu, iż województwa sąsiadujące, mające wspólną historię, rozwijają się w podobny sposób i prawdopodobnie prowadzą zbliżoną politykę aktywizacji rynku pracy.

Na zakończenie należy stwierdzić, że w województwach Polski wyższe wykształcenie determinuje większe szanse na rynku pracy, jednak nie można zgodzić się ze stwierdzeniem, że stopa bezrobocia maleje wraz ze wrorostem poziomu wykształcenia [Klonowska-Matynia, Radlińska, 2009, s. 107]. Badania wykazały, że w ostatnich latach w naszym kraju wśród osób z wykształceniem średnim ogólnokształcącym zaobserwowano dużo mniejszy spadek stopy bezrobocia niż wśród grupy z wykształceniem zasadniczym zawodowym. Wiąże się z tym postulat, że szkoły kształcące na poziomie zawodowym, tak chętnie likwidowane w latach dziewięćdziesiątych XX wieku [Stasiak, 2011, s. 345], powinny zostać przywrócone, gdyż kształcą pracowników poszukiwanych na rynku pracy. Stąd szansa jest planowane odbudowanie szkolnictwa zawodowego w najbliższych latach. Będzie wymagało to oczywiście dużych nakładów finansowych, ponieważ kształcenie zawodowe należy dostosować do aktualnych potrzeb rynku pracy, lecz w dłuższym okresie z pewnością przyczyni się do wzrostu konkurencyjności i produktywności polskiej gospodarki.

Wnioski zaprezentowane w powyższym artykule oparto na badaniach dotyczących rynku pracy w województwach Polski, w latach 2005-2015. Ocenę zmian stóp bezrobocia w tych województwach przeprowadzono ze względu na wykształcenie, niezależnie od przepływów zasobów siły roboczej na rynku pracy.

\section{Wkład autorów w powstanie artykułu}

dr Beata Madras-Kobus - opracowanie części wstępnej (teoretycznej), opracowanie wyników badania - 50\%

dr hab. Józef Rogowski, prof. UwB - opracowanie koncepcji badania, zebranie danych, obliczenia stóp bezrobocia - 50\% 


\section{Literatura}

Aktywność ekonomiczna ludności Polski I kwartat 2015, 2015, Warszawa.

Bezrobocie rejestrowane I kwartat 2016 rok, 2016, GUS, Warszawa.

Fundusze Europejskie w Polsce. Biuletyn Informacyjny, 2014, nr 34, czerwiec, Ministerstwo Infrastruktury i Rozwoju, Warszawa.

https://bdl.stat.gov.pl/BDL/start (data wejścia: 11.03.2016).

Klonowska-Matynia M., Radlińska K., 2009, Rola ksz̨tałcenia kapitału ludzkiego wobec potrzeb rynku pracy w obszarze MSP w Polsce, [w:] Rynek, pracy w Polsce w dobie integracii europejskiej i globalizacji, M. Noga, M. K. Stawicka (red.), Wydawnictwo CeDeWu, Warszawa.

Kołodziejczak W., Wysocki F., 2013, Identyfikacja charaktern bezrobocia w Polsce w latach 2006-2009, „Gospodarka Narodowa”, nr 9, Oficyna Wydawnicza Szkoły Głównej Handlowej, Warszawa.

Kozek W., 2013, Rynek pracy. Perspektywa instytucjonalna, Wydawnictwo Uniwersytetu Warszawskiego, Warszawa.

Madras-Kobus B., Rogowski J., 2013, Analiza mynikón badania stóp bezrobocia wedtug wylkształcenia w województwie podlaskim, „Optimum. Studia Ekonomiczne”, $\mathrm{nr}$ 6(66).

Nagaj R., 2009, Rynek, pracy w Polsce a integracja europejska, [w:] Rynek, pracy w Polsce w dobie integracij europejskiej i globalizacji, M. Noga, M. K. Stawicka (red.), Wydawnictwo CeDeWu, Warszawa.

Pociecha J., Podolec B., Sokołowski A., Zając K., 1988, Metody taksonomiczne w badaniach spoteczno-ekonomicznych, Państwowe Wydawnictwo Naukowe, Warszawa.

Stasiak J., 2011, System edukacji wobec wyzwań rynku pracy w Polsce, [w:] Konkurencyjność i innowacyjność gospodarki a besrobocie, „Folia Oeconomica” 248, Wydawnictwo Uniwersytetu Łódzkiego, Łódź.

Szydlik-Leszczyńska A., 2012, Funkcjonowanie wspótczesnego rynku pracy. Wybrane uwarunkowania, Wydawnictwo Difin, Warszawa. 